\title{
Chemokines in bronchoalveolar lavage fluid in summer-type hypersensitivity pneumonitis
}

\author{
Y. Sugiyama*, T. Kasahara**, N. Mukaida ${ }^{+}$, K. Matsushima+, S. Kitamura*
}

\begin{abstract}
Chemokines in bronchoalveolar lavage fluid in summer-type hypersensitivity pneumonitis. Y. Sugiyama, T. Kasahara, N. Mukaida, K. Matsushima, S. Kitamura. @ERS Journals Ltd 1995.

ABSTRACT: Hypersensitivity pneumonitis (HP) is a granulomatous interstitial lung disease caused by the inhalation of a variety of antigens and is characterized by a dramatic accumulation of inflammatory cells, including neutrophils, lymphocytes and macrophages, in the lung. The mechanisms implicated in the inflammatory cell recruitment observed in hypersensitivity pneumonitis are unknown.

We examined the concentrations of two important chemokines, interleukin-8 (IL8) and monocyte chemoattractant protein-1/monocyte chemotactic and activating factor (MCP-1/MCAF), in the bronchoalveolar lavage fluid (BALF) of patients with summer-type hypersensitivity pneumonitis $(n=8)$, and compared them with those in patients with sarcoidosis $(n=13)$ and with controls $(n=8)$.

In the BALF of summer-type hypersensitivity pneumonitis, the levels both of IL8 and MCP-1 were significantly increased compared with levels measured in control subjects. On the other hand, compared to the control value, the MCP-1 level in the BALF of the sarcoidosis patients was significantly increased, but IL-8 was only slightly and nonsignificantly increased.

Since IL-8 is a chemoattractant for neutrophils and T-lymphocytes, whereas MCP1 acts mainly on monocytes/macrophages, our findings may indicate that these two chemokines participate in the cellular accumulation observed in hypersensitivity pneumonitis.
\end{abstract}

Eur Respir J., 1995, 8, 1084-1090.

\begin{abstract}
*Dept of Pulmonary Medicine, and **Depts of Medical Biology and Parasitology and Microbiology, Jichi Medical School, Minamikawachi-machi, Tochigi-ken, Japan. +Dept of Pharmacology, Cancer Research Institute, Kanazawa University, Kanazawa, Japan.
\end{abstract}

Correspondence: Y. Sugiyama

Dept of Pulmonary Medicine

Jichi Medical School

Minamikawachi-machi

Tochigi-ken

329-04 Japan

Keywords: Bronchoalveolar lavage hypersensitivity pneumonitis interleukin-8

monocyte chemoattractant protein-1

Received: August 311994

Accepted after revision March 151995
Hypersensitivity pneumonitis (HP) is a granulomatous interstitial lung disease caused by the inhalation of a variety of environmental antigens that elicit an inflammatory response in the lung [1]. HP is characterized by a marked cellular influx and accumulation of inflammatory cells in the lungs in patients exposed to certain antigens. In the early phases of the disease, neutrophil infiltration is apparent after exposure to the causative antigen [2]. Later phases of the response are characterized by accumulation of macrophages and lymphocytes, mostly of the CD8+ subset [3]. Activated macrophages and lymphocytes may play a role in amplifying the magnitude of the lung inflammatory response in HP [4, 5]. The humoral responses against the offending agents are not correlated with the disease process [1]. The relative contributions of the different cell types and their mediators in promoting the disease are still unclear, but the participation of various cytokines and chemokines is probable.

Recently, the chemokine known as interleukin-8 (IL8 ), which is a member of a superfamily of cell typespecific leucocyte-attracting and activating peptides, was purified, sequenced and cloned [6-8]. IL-8 is produced in vitro by several cell types, including alveolar macrophages, fibroblasts [9], lymphocytes, and endothelial [10] as well as epithelial cells [11], in response to a number of stimuli, such as lipopolysaccharide (LPS), interleukin-1 (IL-1) and tumour necrosis factor- $\alpha$ (TNFa) [12]. At high concentrations, IL-8 acts as a specific chemoattractant for neutrophils, but at lower concentration it affects lymphocytes [13].

Monocyte chemoattractant protein-1 or monocyte chemotactic and activating factor (MCP-1/MCAF) is another chemokine which has been identified [14-16] and is expressed and released by a variety of cell types, including leucocytes, smooth muscle cells, endothelial cells, fibroblasts, epithelial cells, and alveolar macrophages $[14,17]$. MCP-1 was shown to have a selective chemotactic activity for mononuclear phagocytes and to play an important role in monocyte/macrophage recruitment [14].

In HP, the analysis of bronchoalveolar lavage fluid (BALF) has revealed an increase of total cell number, including alveolar macrophages, and a transient increase of neutrophil number in the early phase, followed by lymphocytosis. This course of cellular accumulation may suggest the participation of IL- 8 and MCP-1 in the processes of HP. In order to examine this hypothesis, 
we measured the concentrations of IL-8 and MCP-1 in BALF from patients with summer-type HP, which is the most frequent type of HP in Japan [18], and compared these concentrations with those in patients with sarcoidosis and with controls.

\section{Methods}

\section{Patients with HP}

Eight patients with summer-type hypersensitivity pneumonitis (ST-HP) (two males and six females; age (mean \pm SD) $48 \pm 11$ yrs; range, 34-61 yrs) were studied. All patients were in the acute stage and newly diagnosed. Four were nonsmokers, two were ex-smokers and two were current smokers. None were receiving corticosteroids. The interval between the last exposure to specific antigens and bronchoalveolar lavage (BAL) ranged 1-20 days (mean 6.5 \pm 6.0 days). The ST-HP in all of the patients completely fulfilled the diagnostic criteria of the Research Committee of Diffuse Respiratory Diseases in Japan [18], i.e. the ST-HP had been diagnosed based on the appearance of symptoms in summer, with cough, remittent fever, and dyspnoea following exposure to the causative agents, and the detection of diffuse nodular or ground glass shadows on the chest roentgenograph, antiTrichosporon cutaneum antibody in the serum, and alveolitis, Masson's body, as well as granulomas in the specimens of transbronchial lung biopsy. ST-HP is confined to Japan, and is caused by inhalation of seasonal molds that contaminate the home environment during the hot and humid summer season. The causative agent of ST-HP is Trichosporon cutaneum, an imperfect yeast [19]. All patients had the acute form of the disease with malaise, shivers, dyspnoea, and cough.

\section{Patients with sarcoidosis}

Thirteen active, untreated and newly diagnosed patients with pulmonary sarcoidosis (two males and 11 females; age (mean \pm SD) $43 \pm 18$ yrs) were evaluated. They all had a clinical background consistent with the diagnosis of sarcoidosis, together with biopsy evidence of noncaseating, epithelioid cell granulomas, and no evidence of mycobacterial, fungal, or parasitic infections. None had a history of exposure to any organic or inorganic material known to cause granulomatous lung disease, nor was any patient being treated with corticosteroids. Eight were nonsmokers and five were current smokers.

\section{Control subjects}

The control group consisted of eight subjects (five males and three females; age (mean \pm SD) $45 \pm 12$ yrs) with no evidence of diffuse respiratory disease. They underwent bronchoscopy as a diagnostic procedure performed to evaluate a history of minor haemoptysis, a solitary peripheral lung nodule $(<2 \mathrm{~cm})$, or other minor radiological findings on their chest roentgenogram. All control patients had comparable lung function within the normal range as determined by routine spirometry. None of the patients were receiving corticosteroids and other drugs orally or by inhalation. Four were nonsmokers and five were current smokers.

Informed consent was obtained from each patient in the study according to institutional guidelines.

\section{Bronchoalveolar lavage and fluid processing}

BAL was performed using standard techniques [20]. Sterile normal saline at room temperature was instilled through a bronchoscope in $50 \mathrm{~mL}$ aliquots to a total volume of $150 \mathrm{~mL}$, with harvesting of the fluid by immediate gentle hand suctioning applied to each instilling syringe. Differential counts were performed using WrightGiemsa-stained cytocentrifuge specimens prepared using a cytospin. The pooled BALF was centrifuged at $800 \times \mathrm{g}$ for $10 \mathrm{~min}$. The supernatant fluid was frozen at $-70^{\circ} \mathrm{C}$ until use. Before the assay, $10 \mathrm{~mL}$ of supernatant fluid was concentrated to approximately $1 \mathrm{~mL}$ using a Centricon 3 (Amicon, Beverly, MA, USA).

\section{Quantification of IL-8 and MCP-1 levels in BALF}

IL-8, MCP-1, and albumin levels were measured in the 10 fold concentrated BALF samples.

IL-8 and MCP-1 assay. The IL-8 level was determined using an enzyme-linked immunosorbent assay (ELISA), by using monoclonal antibody (clone WS4) as a capturing antibody $(\mathrm{Ab})$ and rabbit $\mathrm{Ab}$ as a second $\mathrm{Ab}$, both of which were raised against human recombinant IL-8 (rIL-8 of 72 amino acid form (gift from Dainippon Pharmaceutical Co., Osaka, Japan)), as described previously [21]. The detection limit of this assay was $20 \mathrm{pg}$ of IL-8 per mL. The specificity of this ELISA system was established in that the WS4 did not cross-react with other chemokines, including MCP-1, platelet factor 4, beta-thromboglobin, MIP-1 alpha/beta, RANTES, IL-1 $\alpha$, and TNF- $\alpha$.

For the MCP-1 assay, a Sandwich ELISA was developed using biotinylated polyclonal rabbit anti-human MCP-1 antibody with rMCP-1 (Peprotech; Rocky Hill, NJ, USA) as a standard [21]. The sensitivity of this system was found to be $40 \mathrm{pg}$ of MCP-1 per mL. The specificity of this assay was confirmed by observation of no cross-reaction of this antibody with IL-8, RANTES, MIP-1 alpha/beta, IL- $1 \alpha$, or TNF- $\alpha$. Both the ELISA systems were tested with known quantities of IL-8 and MCP-1 in control BALF. All of the samples were assayed at least in duplicate.

The relationship between the levels of these two chemokines, IL- 8 and MCP-1, in the patients with ST$\mathrm{HP}$ was examined using linear regression analysis.

Albumin assay. Albumin was measured in the concentrated BALF via a specific radio-immunoassay.

Evaluation of BALF characteristics and their relationship to the levels of chemokines in subjects groups. We examined the following BALF characteristics in the 
Table 1. - Clinical and BAL characteristics of patients with summer-type hypersensitivity pneumonitis

\begin{tabular}{|c|c|c|c|c|c|c|c|c|c|c|c|c|c|}
\hline \multirow{2}{*}{$\begin{array}{l}\mathrm{Pt} \\
\text { No. }\end{array}$} & \multirow{2}{*}{$\begin{array}{l}\text { Age } \\
\text { yrs }\end{array}$} & \multirow[t]{2}{*}{ Sex } & \multirow[t]{2}{*}{$\begin{array}{l}\text { Tobacco } \\
\text { pack-yrs }\end{array}$} & \multirow{2}{*}{$\begin{array}{c}\text { Time since } \\
\text { last exposure } \\
\text { days }\end{array}$} & \multirow[t]{2}{*}{$\begin{array}{c}\mathrm{VC} \\
\% \text { pred }\end{array}$} & \multicolumn{2}{|c|}{$\begin{array}{c}P \mathrm{a}, \mathrm{O}_{2} \\
\text { at rest }\end{array}$} & \multirow[t]{2}{*}{$\begin{array}{l}T_{\mathrm{L}, \mathrm{CO}} \\
\% \text { pred }\end{array}$} & \multirow{2}{*}{$\begin{array}{c}\text { Total } \\
\text { cells } \\
\times 10^{6} \cdot \mathrm{mL}^{-1}\end{array}$} & \multirow[t]{2}{*}{$\underset{\%}{\mathrm{AM}}$} & \multirow[t]{2}{*}{$\begin{array}{c}\text { Granulo } \\
\%\end{array}$} & \multirow[t]{2}{*}{$\begin{array}{c}\text { Lympho } \\
\%\end{array}$} & \multirow[t]{2}{*}{$\begin{array}{c}\mathrm{CD} 4 / \mathrm{CD} 8 \\
\text { ratio }\end{array}$} \\
\hline & & & & & & Torr & $\mathrm{kPa}$ & & & & & & \\
\hline 1 & 36 & M & 37.5 & 7 & 120 & 53.8 & 7.2 & 63 & 0.88 & 15.0 & 4.0 & 81.0 & 0.21 \\
\hline 2 & 56 & $\mathrm{~F}$ & $(-)$ & 1 & 79 & 62.4 & 8.3 & 61 & 1.33 & 43.4 & 8.3 & 48.3 & 0.52 \\
\hline 3 & 37 & M & Ex & 1 & 107 & 71.6 & 9.5 & 88 & 1.97 & 16.0 & 1.5 & 82.5 & 0.15 \\
\hline 4 & 53 & $\mathrm{~F}$ & $(-)$ & 5 & 74 & 57.0 & 7.6 & 38 & 1.80 & 8.8 & 5.5 & 85.7 & 0.54 \\
\hline 5 & 34 & $\mathrm{~F}$ & $(-)$ & 6 & 53 & 53.1 & 7.1 & 24 & 0.95 & 19.1 & 4.6 & 79.3 & 0.74 \\
\hline 6 & 61 & $\mathrm{~F}$ & $(-)$ & 7 & 75 & 53.4 & 7.1 & 52 & 0.48 & 9.8 & 4.0 & 86.2 & 0.65 \\
\hline 7 & 60 & $\mathrm{~F}$ & Ex & 5 & 99 & 56.9 & 7.6 & 49 & 1.39 & 9.0 & 2.7 & 88.3 & 0.17 \\
\hline 8 & 50 & $\mathrm{~F}$ & 15.0 & 20 & 106 & 40.7 & 5.4 & 77 & 0.71 & 17.7 & 18.4 & 63.9 & 0.25 \\
\hline \multirow{2}{*}{\multicolumn{2}{|c|}{$\begin{array}{l}\text { Mean } \\
\pm \text { SD }\end{array}$}} & & & 6.5 & 89 & 56.1 & 7.5 & 57 & 1.19 & 17.4 & 6.1 & 76.9 & 0.40 \\
\hline & & & & \pm 6.0 & \pm 22 & \pm 8.8 & \pm 1.2 & \pm 21 & \pm 0.52 & \pm 11.3 & \pm 5.3 & \pm 13.8 & \pm 0.23 \\
\hline
\end{tabular}

BAL: bronchoalveolar lavage; Pt: patient; VC: vital capacity; $P_{\mathrm{a}, \mathrm{O}_{2}}$ : arterial oxygen tension; $\mathrm{T}_{\mathrm{L}, \mathrm{CO}}$ : transfer factor of the lungs for carbon monoxide; AM: alveolar macrophage; Granulo: granulocyte; Lympho: lymphocyte; M: male; F: female.

patients with ST-HP and all subjects: total cell number, percentage and absolute number of macrophages, lymphocytes and granulocytes, and their relationship to the concentrations of IL- 8 and MCP-1.

\section{Statistical analysis}

All values are expressed as mean \pm SD. Analysis of data was performed using the nonparametric Mann-Whitney U-test. Simple linear correlation (Pearson's r) was employed to evaluate the relationship between IL- 8 and MCP-1 levels in BALF. A p-value of less than 0.05 was considered significant.

\section{Results}

\section{Analysis of cells in BALF}

Table 1 shows the clinical and BAL characteristics of the eight patients with ST-HP. The absolute number of cells recovered from lavage in these patients was markedly elevated (mean \pm SD $1.19 \pm 0.52 \times 10^{6}$ cells $\cdot \mathrm{mL}^{-1} ; \mathrm{n}=8$ ), as was the \% lymphocytes (77 \pm 14$)$, with a low CD4/CD8 ratio (mean $0.40 \pm 0.23$ ). Table 2 shows the BAL characteristics of the three groups.

\section{IL-8 and MCP-1 levels in BALF samples}

IL-8 and MCP-1 were detectable in every 10 fold concentrated BALF sample in all of the subjects. The data shown here are normalized to crude concentrations. As shown in figure 1 , the levels of IL- 8 and MCP-1 in the BALF of the patients with ST-HP were significantly higher than those both in the subjects with sarcoidosis and the controls. When normalized to albumin, the level of IL-8 in the BALF of the patients with ST-HP (30.8 \pm $22.3 \mathrm{pg} \cdot \mathrm{mg}^{-1}$ albumin) was significantly higher than that in the subjects with sarcoidosis $\left(11.7 \pm 13.6 \mathrm{pg} \cdot \mathrm{mg}^{-1}\right.$ albu$\min ; \mathrm{p}<0.05)$ and in controls $\left(7.4 \pm 10.3 \mathrm{pg} \cdot \mathrm{mg}^{-1}\right.$ albumin; $\mathrm{p}<0.005$ ) (fig. 2a). When normalized to albumin, the level of MCP-1 in the BALF of the patients with STHP $\left(33.4 \pm 22.7 \mathrm{pg} \cdot \mathrm{mg}^{-1}\right.$ albumin) was also significantly higher than that in the controls $\left(10.6 \pm 10.3 \mathrm{pg} \cdot \mathrm{mg}^{-1}\right.$ albumin; $\mathrm{p}<0.01)$, but it showed no significant difference from that in the sarcoidosis group $\left(45.0 \pm 27.4 \mathrm{pg} \cdot \mathrm{mg}^{-1}\right.$ albumin) (fig. 2b).

Five of the patients with sarcoidosis showed a significant lymphocytosis above $40 \%$ (mean \pm SD $67 \pm 15 \%$ ) in BALF samples. The mean \pm sD level of IL-8 (30.8 \pm 22.3 $\mathrm{pg} \cdot \mathrm{mg}^{-1}$ albumin) in the ST-HP patients was significantly higher than that in the five sarcoidosis patients with lymphocytosis $\left(5.9 \pm 7.5 \mathrm{pg} \cdot \mathrm{mg}^{-1}\right.$ albumin; $\left.\mathrm{p}<0.01\right)$, but there was no difference between these groups in the level of MCP-1 (33.4 $\pm 22.7 \mathrm{pg} \cdot \mathrm{mg}^{-1}$ albumin and $40.6 \pm 29.2$

Table 2. - Patient's BAL features

\begin{tabular}{|c|c|c|c|c|c|c|c|c|}
\hline $\begin{array}{l}\text { Group } \\
\text { (n) }\end{array}$ & $\mathrm{S} / \mathrm{NS}$ & $\begin{array}{l}\text { Age } \\
\text { yrs }\end{array}$ & $\begin{array}{c}\text { BAL } \\
\text { recovery } \\
\%\end{array}$ & $\begin{array}{c}\text { Total } \\
\text { cells } \\
\times 10^{6} \cdot \mathrm{mL}^{-1}\end{array}$ & $\mathrm{AM}$ & tology results & Granulo & $\begin{array}{l}\text { Mean } \\
\text { albumin } \\
\mathrm{mg} \cdot \mathrm{dL}^{-1}\end{array}$ \\
\hline $\begin{array}{l}\text { Normals } \\
(\mathrm{n}=8)\end{array}$ & $4 / 4$ & $45 \pm 14$ & $56 \pm 10$ & $0.38 \pm 0.26$ & $\begin{array}{l}88.7 \\
\pm 7.8\end{array}$ & $\begin{array}{r}10.4 \\
\pm 7.6\end{array}$ & $\begin{array}{r}0.9 \\
\pm 0.4\end{array}$ & 4.00 \\
\hline $\begin{array}{l}\text { ST-HP } \\
(n=8)\end{array}$ & $2 / 6$ & $48 \pm 11$ & $44 \pm 12$ & $1.19 \pm 0.52$ & $\begin{array}{r}17.4 \\
\pm 11.3\end{array}$ & $\begin{array}{r}76.9 \\
\pm 13.8\end{array}$ & $\begin{array}{r}6.1 \\
\pm 5.3\end{array}$ & 25.23 \\
\hline $\begin{array}{l}\text { Sarcoid } \\
(n=13)\end{array}$ & $5 / 8$ & $42 \pm 18$ & $58 \pm 9$ & $0.31 \pm 0.16$ & $\begin{array}{r}63.2 \\
\pm 28.3\end{array}$ & $\begin{array}{r}38.1 \\
\pm 26.9\end{array}$ & $\begin{array}{r}1.0 \\
\pm 0.7\end{array}$ & 9.53 \\
\hline
\end{tabular}

Data are presented as mean \pm SD. Mean BAL recovery $(\%)$ of $150 \mathrm{~mL}$ instilled. S: current smoker; NS: nonsmoker and ex-smoker. For further abbreviations see legend to table 1. 

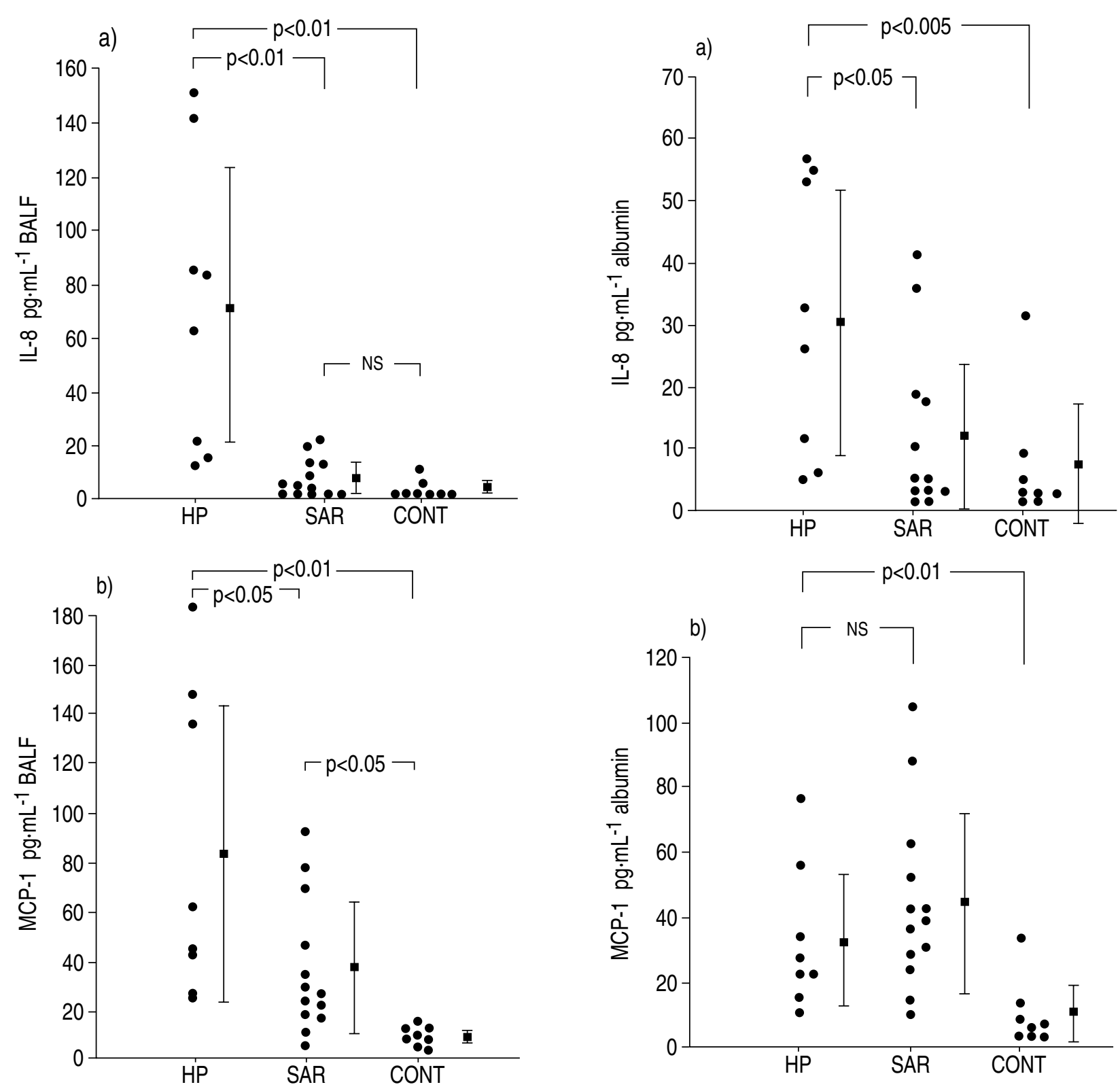

Fig. 1. - Concentrations (mean \pm SD) of: a) IL-8; and b) MCP-1 in BALF from patients with ST-HP (HP), sarcoidosis (SAR) and control (CONT) subjects. The results are expressed as pg of IL-8 or MCP-1 per mL of BALF. IL-8: interleukin-8; MCP-1: monocyte chemoattractant protein-1; BALF: bronchoalveolar lavage fluid; ST-HP: summer-type hypersensitivity pneumonitis; ns: nonsignificant.

$\mathrm{pg} \cdot \mathrm{mg}^{-1}$ albumin, respectively). These data suggest that MCP-1 may play a role in cell accumulation both in ST-HP and sarcoidosis.

Relationship between BALF IL-8 and MCP-1 in patients with ST-HP

Linear regression analysis demonstrated no significant correlation between the BALF IL-8 and MCP-1 levels in the patients with ST-HP $(r=0.366 ; n=8)$. These data suggest that the production and/or degradation/clearance of each chemokine is regulated differentially.

Fig. 2. - Concentrations (mean \pm SD) of: a) IL- 8 protein; and b) MCP1 normalized to albumin in BALF from patients with ST-HP, sarcoidosis and control subjects. The results are expressed as pg of IL-8 or MCP-1 per mg of albumin. For abbreviations see legend to figure 1 .

Relationship of BALF characteristics to the levels of IL8 and MCP-1 in the patients with ST-HP and in all subjects

There was no significant correlation between BALF characteristics and the concentrations of chemokines in the patients with ST-HP. Analysis of data in all subjects revealed significantly positive correlations between the absolute number of lymphocytes and IL- 8 level, absolute number of granulocytes and IL-8 level, total cell number and MCP-1 level, and absolute number of lymphocytes and MCP-1 level (fig. 3). These data and the biological activity of these two chemokines suggest that IL- 8 and MCP-1 may participate in the accumulation of inflammatory cells in these granulomatous and interstitial lung diseases. 

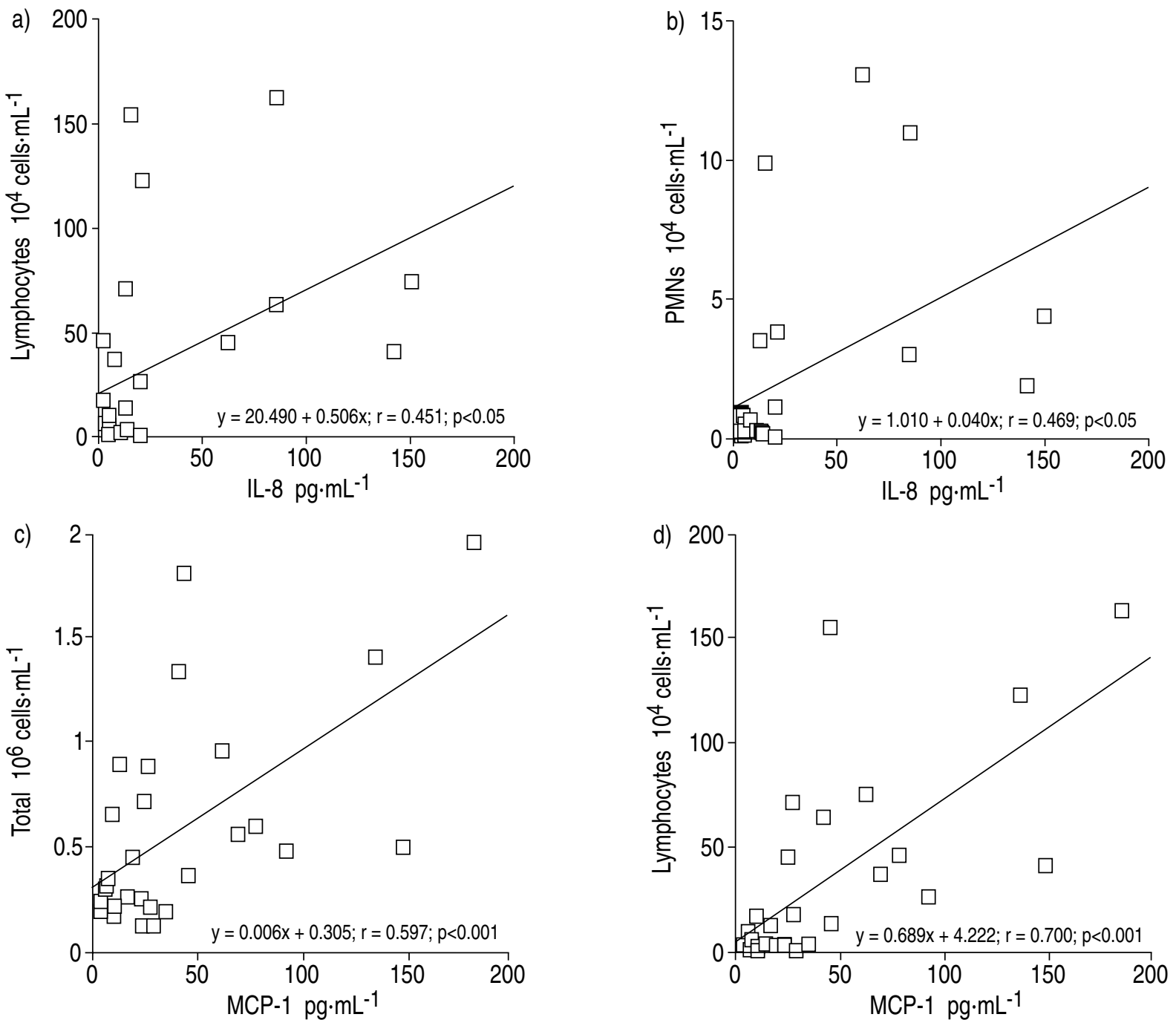

Fig. 3. - Relationship between BALF characteristics and the levels of chemokines in all subjects. Shown on the ordinate and abscissa are: a) absolute number of lymphocytes in BALF and the level of IL-8 (pg.mL-1 BALF); b) absolute number of granulocytes in BALF and the level of IL-8 (pg. $\mathrm{mL}^{-1}$ BALF); c) total number of cells in BALF and the level of MCP-1 (pg.mL-1 BALF); and d) absolute number of lymphocytes in BALF and the level of MCP-1 (pg.mL $\left.\mathrm{mL}^{-1} \mathrm{BALF}\right)$. PMN: polymorphonuclear neutrophils. For further abbreviations see legend to figure 1.

\section{Discussion}

Our findings demonstrate elevation of the levels of two important inflammatory chemokines, IL-8 and MCP1 , in BALF from untreated symptomatic patients with ST-HP. In contrast, elevation of IL-8 level was lower in the BALF from sarcoidosis patients, even in those with significant lymphocytosis in BALF. It has been reported that only low levels of IL- 8 messenger ribonucleic acid (mRNA) were detected in BAL cells isolated from patients with pulmonary sarcoidosis [22]. On the other hand, CAR et al. [23] reported elevated IL-8 in BALF of patients with sarcoidosis. In contrast, even in our sarcoidosis group with lymphocytosis, the level of IL-8 was not elevated. The discrepancy between our findings and those of CAR et al. [23] remains unclear, at present. In HP, an immediate and transient neutrophil alveolitis occurs after antigen inhalation [2]. After this immediate stage, a significant lymphocytosis with a slight increase of neutrophil number is observed in BALF. The elevated IL-8 level in the BALF of patients with ST-HP seems most probably related to the accumulation of neutrophils in the interstitium that can be observed in the early stages of hypersensitivity pneumonitis. YoshizawA et al. [24] reported that active chemotactic factors for polymorphonuclear cells could be correlated with the level of C5a des Arg in BALF but not with leukotriene $\mathrm{B}_{4}$ in ST-HP [24]. Further investigations will be needed to clarify the role of C5a.

Recently, DenIs et al. [25] reported that Micropolyspora faeni, which is a causative antigen of a form of HP known as farmer's lung, directly stimulates the secretion of TNF by alveolar macrophages. TNF is known to stimulate various cells, including alveolar macrophages, for increased IL-8 production [26]. These observations, together with our finding of the elevation of IL-8 in BALF in ST-HP patients, suggest that IL-8 plays a prominent role in the cell accumulation seen in the lung in this disease. In the BALF of the ST-HP patients, the level of MCP-1, which has a selective chemotactic activity for mononuclear phagocytes, was also elevated. The increased levels of these two chemokines suggest, as a 
possible causative mechanism in the lung in HP, the recruitment of neutrophils and/or lymphocytes induced by IL-8; with MCP-1 playing a role in acceleration of the inflammatory process by the accumulation of mononuclear phagocytes at the inflammatory sites in ST-HP. In the cytokine network model in the lung, alveolar macrophages initially respond to a stimulus by secreting TNF and/or IL-1. These cytokines then act in an autocrine or paracrine fashion, leading to interleukin-6 (IL6) and IL-8 release by macrophages, epithelial cells or fibroblasts, and triggering an inflammatory response involving neutrophils, macrophages and lymphocytes. The course of inflammation which occurs in ST-HP may be explained by this model.

The participation of IL- 8 has been reported in various diseases and conditions. It has been demonstrated that the expression of the IL- 8 gene by alveolar macrophages is increased in idiopathic pulmonary fibrosis (IPF), and IL-8 derived from alveolar macrophages may significantly contribute to neutrophil involvement in the pathogenesis of IPF $[22,27]$. The reported concentration of IL-8 in BALF derived from patients with IPF is $58.5 \pm 11.2$ $\mathrm{pg} \cdot \mathrm{mg}^{-1}$ [27]. Although it is difficult to directly compare our data with the data in IPF, the IL-8 level in our ST-HP patients might be even higher than that reported in IPF [27].

When the pulmonary content of alveolar macrophages is increased during acute inflammatory episodes, elaboration by the lung of monocyte-specific chemoattractants with recruitment of more mononuclear cells has been suggested [28]. MCP-1 may be a prime candidate for such a chemoattractant, since BRIELAND et al. [29] demonstrated that alveolar macrophages themselves are a source of MCP-1, raising the interesting possibility of a positive feedback mechanism in the recruitment of alveolar macrophages.

In conclusion, the levels both of IL- 8 and MCP- 1 were significantly increased in the BALF of ST-HP, and our findings may indicate that these two chemokines participate in the cellular accumulation observed in HP.

Acknowledgement: The authors thank S. Su, Department of Pharmacology, Cancer Research Institute, Kanazawa University, for technical assistance.

\section{References}

1. Schuyler M, Salvaggio J. Hypersensitivity pneumonitis. Semin Respir Med 1984; 5: 246-254.

2. Drent M, van Velzen-Blad H, Diamant M, Wagenaar SS, Hoogsteden HC, van den Bosch JMM. Bronchoalveolar lavage in extrinsic allergic alveolitis: effect of time elapsed since antigen exposure. Eur Respir J 1993; 6: 12761281.

3. Milburn HJ. Lymphocyte subsets in hypersensitivity pneumonitis. Eur Respir J 1992; 5: 5-7.

4. Stankus RP, Cashner F, Salvaggio JE. Bronchopulmonary macrophage activation in the pathogenesis of hypersensitivity pneumonitis. J Immunol 1978; 120: 685691.
5. Mornex JF, Cordier G, Pages J. Activated lung lymphocytes in hypersensitivity pneumonitis. J Allergy Clin Immunol 1984; 74: 719-728.

6. Yoshimura T, Matsushima K, Oppenheim JJ, Leonard EJ. Neutrophil chemotactic factor produced by lipopolysaccharide (LPS) stimulated blood mononuclear leukocytes. I. Partial characterization and separation from interleukin-1 (IL-1). J Immunol 1987; 139: 788-793.

7. Yoshimura T, Matsushima K, Tanaka S. Purification of a human monocyte-derived neutrophil chemotactic factor that shares sequence homology with other host defense cytokines. Proc Natl Acad Sci USA 1987; 84: 92339237.

8. Matsushima K, Morishita K, Yoshimura T, et al. Molecular cloning of a human monocyte-derived neutrophil chemotactic factor (MDNCF) and the induction of MDNCF mRNA by interleukin-1 and tumor necrosis factor. $J$ Exp Med 1988; 167: 1883-1893.

9. Strieter RM, Phan SH, Showell HJ, et al. Monokineinduced neutrophil chemotactic factor gene expression in human fibroblasts. J Biol Chem 1989; 264: 1062110626.

10. Strieter RM, Kunkel SL, Showell HJ, et al. Endothelial cell gene expression of a neutrophil chemotactic factor by TNF-alpha, LPS, and IL-1beta. Science (Washington, DC) 1989; 243: 1467-1469.

11. Standiford TJ, Kunkel SL, Basha MA, et al. Interleukin8 gene expression by a pulmonary epithelial cell line: a model for cytokine networks in the lung. J Clin Invest 1990; 86: 1945-1953.

12. Baggiolini M, Walz A, Kunkel SL. Neutrophil-activating peptide-1/interleukin- 8 , a novel cytokine that activates neutrophils. J Clin Invest 1989; 84: 1045-1049.

13. Larsen CG, Anderson AO, Appella E, Oppenheim JJ, Matsushima K. The neutrophil-activating protein (NAP1 ) is also chemotactic for T-lymphocytes. Science 1989; 243: 1464-1466.

14. Yoshimura T, Robinson EA, Tanaka S, Appella E, Leonard EJ. Purification and amino acid analysis of two human monocyte chemoattractants produced by phytohemagglutinin-stimulated human blood mononuclear leukocytes. J Immunol 1989; 142: 1956-1962.

15. Furutani Y, Nomura HN, Notake M, et al. Cloning and sequencing of the cDNA for human monocyte chemoattractant and activating factor (MCAF). Biochem Biophys Res Commun 1989; 159: 249-255.

16. Matsushima K, Larsen CG, DuBois GC, Oppenheim JJ. Purification and characterization of a novel monocyte chemotactic and activating factor produced by a human myelomonocyte cell line. J Exp Med 1989; 169: 14841490.

17. Antoniades HN, Neville-Golden J, Galanopoulos T, Kradin RL, Valente AJ, Graves DT. Expression of monocyte chemoattractant protein-1 mRNA in human idiopathic pulmonary fibrosis. Proc Natl Acad Sci USA 1992; 89: 5371-5375.

18. Ando M, Arima K, Yoneda R, Tamura M. Japanese summer-type hypersensitivity pneumonitis. Am Rev Respir Dis 1991; 144: 765-769.

19. Shimazu K, Ando M, Sakata T, Yoshida K, Araki S. Hypersensitivity pneumonitis induced by Trichosporon cutaneum. Am Rev Respir Dis 1984; 130: 407-411.

20. The BAL Co-operative Group Steering Committee. Bronchoalveolar lavage constituents in healthy individuals, idiopathic pulmonary fibrosis, and selected comparison group. Am Rev Respir Dis 1990; 141: S188S192. 
21. Kasahara T, Mukaida N, Yamashita K, Yagisawa H, Akahoshi T, Matsushima K. IL-1 and TNF-alpha induction of IL-8 and monocyte chemotactic and activating factor (MCAF) mRNA expression in a human astrocytoma cell line. Immunology 1991; 74: 60-67.

22. Lynch III JP, Standiford TJ, Rolfe MW, Kunkel SL, Strieter RM. Neutrophilic alveolitis in idiopathic pulmonary fibrosis. The role of interleukin-8. Am Rev Respir Dis 1992; 145: 1433-1439.

23. Car BD, Meloni F, Luisetti M, Semenzato G, GialdroniGrassi G, Walz A. Elevated IL-8 and MCP-1 in the bronchoalveolar lavage fluid of patients with idiopathic pulmonary fibrosis and pulmonary sarcoidosis. $A m J$ Respir Crit Care Med 1994; 149: 655-659.

24. Yoshizawa Y, Nomura A, Ohdama S, Tanaka M, Morinari $\mathrm{H}$, Hasegawa $\mathrm{S}$. The significance of complement activation in the pathogenesis of hypersensitivity pneumonitis: sequential changes of complement components and chemotactic activities in bronchoalveolar lavage fluids. Int Arch Allergy Appl Immunol 1988; 87: 417-423.

25. Denis M, Cormier Y, Tardif J, Ghadirian E, Laviolette
M. Hypersensitivity pneumonitis: whole Micropolyspora faeni or antigens thereof stimulate the release of proinflammatory cytokines from macrophages. Am J Respir Cell Mol Biol 1991; 5: 198-203.

26. Strieter RM, Chensue SW, Basha MA, et al. Human alveolar macrophage gene expression of interleukin- 8 by tumor necrosis factor-alpha, lipopolysaccharide, and interleukin-1beta. Am J Respir Cell Mol Biol 1990; 2: 321326.

27. Carre PC, Mortenson RL, King Jr TE, Noble PW, Sable CL, Riches DWH. Increased expression of the interleukin-8 gene by alveolar macrophages in idiopathic pulmonary fibrosis. J Clin Invest 1991; 88: 1802-1810.

28. Rollins BJ. "Oh, no, not another cytokine". MCP-1 and respiratory disease. Am J Respir Cell Mol Biol 1992; 7: 126-127.

29. Brieland JK, Jones ML, Clarke SJ, Baker JB, Warren JS, Fantone JC. Effect of acute inflammatory lung injury on the expression of monocyte chemoattractant protein1 (MCP-1) in rat pulmonary alveolar macrophages. $A m$ J Respir Cell Mol Biol 1992; 7: 134-139. 